\title{
The Problems with and Promise of Entrepreneurial Finance
}

\author{
Strategic Entrepreneurship Journal, forthcoming
}

\author{
Douglas Cumming \\ Professor and Ontario Research Chair \\ York University - Schulich School of Business \\ 4700 Keele Street \\ Toronto, Ontario M3J 1P3 \\ Canada \\ http://ssrn.com/author $=75390$ \\ dcumming@schulich.yorku.ca \\ Sofia Johan \\ York University - Schulich School of Business \\ 4700 Keele Street \\ Toronto, Ontario M3J 1P3 \\ Canada \\ http://www.schulich.yorku.ca/ \\ sjohan@schulich.yorku.ca
}

July 31, 2017

\footnotetext{
* We are indebted to Mike Wright and Gary Dushnitsky for encouragement and support, and two anonymous reviewers for their helpful comments. We gratefully acknowledge generous financial support from the Social Sciences and Humanities Research Council of Canada.
} 


\section{The Problems with and Promise of Entrepreneurial Finance}

\section{Abstract \\ Research Summary}

This paper provides a review of the entrepreneurial finance literature in the surprisingly not very well integrated entrepreneurship and finance journals. Entrepreneurial finance encompasses venture capital, private equity, private debt, trade credit, IPOs, angel finance, and crowdfunding, among other forms of finance. We analyze trends in citation activity to these topic areas across sixteen journals that publish at least somewhat regularly on these topics, and show there has been a rise in citations to the venture capital, private equity, and IPOs post-2006. We highlight an unfortunate degree of segmentation in the literature, as well as topics that have been the subject of scholarly focus, and identify promising topics for future research.

\section{Managerial Summary}

Who does research in entrepreneurial finance - entrepreneurship or finance scholars? And why types of journals are more likely to publish research in entrepreneurial finance? In this paper, we provide an overview of the literature on topics that include venture capital, private equity, private debt, trade credit, IPOs, angel finance, and crowdfunding. Our review of the literature shows that some elements of segmentation by the specific topic, which we explain is partly due to the fact that datasets on entrepreneurial finance themselves are often segmented and do not include information on more than one form of entrepreneurial finance at a time. Further, we show citation patterns are segmented by the type of journal, where finance journals are much less likely to refer to entrepreneurship journals. 
Lee Smolin begins The Trouble with Physics (Smolin 2007) by noting that his career spanned the only quarter-century in the history of physics when the field made no progress on its core problems. The trouble with macroeconomics is worse. I have observed more than three decades of intellectual regress.

- Romer (2016)

\section{Introduction}

Entrepreneurial finance encompasses the intersection of the two separate fields of "entrepreneurship" and "finance". The field began with publications first appearing in entrepreneurship journals, such as Research Policy (founded in 1972), Entrepreneurship Theory and Practice (founded in 1976), Strategic Management Journal (founded in 1982), Journal of Business Venturing (founded in 1986). More recently, the new Strategic Entrepreneurship Journal was added in 2007. Apart from studies of initial public offerings (IPOs), topics in entrepreneurial finance only began to appear in finance journals starting in 1990 with studies on the impact of venture capital on initial public offering (IPO) performance (Barry et al., 1990; Megginson and Weiss, 1991), despite the fact that the first finance journal - the Journal of Finance - was founded in 1946. More recently, the Journal of Banking and Finance was founded in 1977 and the Journal of Corporate Finance was founded in 1994, and are two of the mainstream finance journals with a nontrivial proportion of their content focused on topics pertinent to entrepreneurial finance. In this paper, we provide a retrospective and prospective look at the development of entrepreneurial finance in both entrepreneurship and finance journals, and do so by focusing in specific areas that include venture capital, private equity, crowdfunding, angel finance, private debt, trade credit, and IPOs. Our direct and critical analysis is inspired in part by the hard hitting Paul Romer, quoted above.

What makes entrepreneurial finance an interesting area for scholarly examination? Put differently, why should anyone care about how the field develops? Traditional finance models such as the CAPM were developed to study publicly traded companies on stock exchanges. Retail and institutional investors, including professional fund managers such as mutual funds, rarely actively get involved as active investors in the companies in which they trade. In effect, the finance issues are often separated from issues that involve governance provided by the source of capital. Entrepreneurial finance, by contrast, typically involves non-publicly traded companies that have yet to be listed on a stock exchange. Publicly traded firms that are almost always the subject of scholarly examination in finance journals were all once privately held prior to becoming listed on an exchange. And many of the most successful publicly traded companies, such as Apple and Facebook, and some of the most successful acquisitions, such as Hotmail and Skype, were previously venture capital backed companies. Entrepreneurial finance typically involves very active investors that provide strategic, financial, human resource, and marketing advice, as well as an array of connections with lawyers, accountants, consultants, and investment 
banks for entrepreneurs to grow and develop to become large firms, possibly even firms listed on a stock exchange. Hence, there are a huge array of issues in entrepreneurial finance that mix strategy and finance, including topics in fundraising, investing, staging, syndication, financial contracting, and selling companies in initial public offerings and acquisitions. Moreover, with many governments around the world interested in recreating the success of Silicon Valley, there is substantial interest among scholars, practitioners and policymakers alike on the topic of government policy towards entrepreneurial finance.

Research in entrepreneurial finance has had a slow and rocky start due to the dearth of systematic datasets on topic. In most countries (excluding Scandinavian countries and some continental European countries such as France and Belgium), firms are not mandated to disclose information until they are publicly traded on a stock exchange. Hence, the development of early work on finance began with publicly traded companies, not privately held ones. Early research in entrepreneurial finance was largely carried out with the use of surveys. One of the first research centers on entrepreneurial finance, if not the first center, was the Center for Management Buyout Research (CMBOR), ${ }^{1}$ was founded by Professor Mike Wright at the University of Nottingham in 1986. Entrepreneurial finance has tremendous potential to be at the forefront of interdisciplinary research linking the fields of not only entrepreneurship and finance, but also public policy (e.g., Klein, Mahoney, McGahan, and Pitelis, 2013), strategy (e.g., Sirén, Kohtamäki, and Kuckertz, 2012), psychology (e.g., Felin and Zenger, 2009), sociology (e.g., Stuart and Sorenson, 2007), geography (e.g., Coombs, Deeds, and Ireland, 2009), and economics and law (e.g., Cumming, Sapienza, Siegel, and Wright, 2009). The study of entrepreneurship has made tremendous strides in being interdisciplinary across each of these areas. Entrepreneurial finance, by contrast, is different, which gives rise to a certain element of complaint and remorse in this paper, but nevertheless also suggests opportunities for future research.

In this paper, we explain and empirically analyze trends in the development of the literature on entrepreneurial finance. We see a number of things in entrepreneurial finance that are distinct from other fields. Most notably, entrepreneurial finance is a segmented literature across journals in "management/entrepreneurship" and "finance”. This segmentation gives rise to issues that are distinct from fields that are not interdisciplinary. For example, physics and macroeconomics have many journals, but there are not two separate groups of top tier journals for which authors can pick, unlike entrepreneurial finance. This segmentation enables a different type of coevolution of the field which is interesting to analyze.

\footnotetext{
1 http://wwwf.imperial.ac.uk/business-school/research/the-centre-for-management-buy-out-research/ . CMBOR founder Mike Wright often recounts how his senior colleagues at the time thought he was ruining his career by doing so, though that turns out not to have been correct!
} 
In this paper, we empirically analyze a large dataset extracted from Google Scholar regarding reference to different topics in entrepreneurial finance, including venture capital, private equity, IPOs, debt, trade credit, angel finance, and crowdfunding. The data show interesting patterns about the growing interest in these topics post 2006, and factors that affect the development of the field. Also, the data are consistent with a general sentiment that we have noticed in our study of topics at the intersection of entrepreneurship and finance over the last 20 years. That is, the interdisciplinary nature of entrepreneurial finance can be characterized as one that is considered to be interdisciplinary by most scholars in entrepreneurship and not interdisciplinary by most scholars in finance. Specifically, researchers in entrepreneurship often reference research in finance journals, while researchers in finance are much less likely to reference research in entrepreneurship journals. As such, topic development and scientific progress is fragmented and as a result, there have been hurdles to the development of research on entrepreneurial finance in ways that are consistent with Paul Romer's (2016) The Trouble with Macroeconomics and Lee Smolin's (2007) The Trouble with Physics.

In this paper, we are somewhat critical of certain papers. As such, we begin by saying we have no intention of being highly critical of the researchers themselves that wrote those papers and instead at the outset highlight the excellent high quality of the work in general of everyone referenced in this paper. Instead, we merely point out some factual issues with some papers and research in entrepreneurial finance that highlight a high degree of segmentation, among other problems that arguably impede the development of the field. We do so only for the purpose of suggesting improvements to the entrepreneurial finance research culture.

A key theme from our analysis is that the most innovative work in the future will make use of the large benefits that come from an interdisciplinary approach to entrepreneurial finance that draws on not purely finance perspectives but also strategy and management, as well as legal and institutional theory, psychology, and sociology. At the intersection of these areas are the greatest opportunities to be innovative and bring about advancement in theory and empirical testing.

This brief paper is organized as follows. The next section discusses the link between segmented and low quality data and segmented research clubs in entrepreneurial finance across the entrepreneurship and finance journals. The section thereafter introduces Google Scholar citation data, and provides an empirical analysis of those data with reference to the post-2006 period. The last two sections offer some concluding remarks and hopes for the further development of the field of entrepreneurial finance.

\section{A Backgrounder on Interpreting Citation Data in Entrepreneurial Finance}

As explained elsewhere (e.g., Cumming, 2016, and Cumming and Vismara, 2016a,b), research in entrepreneurial finance is highly segmented. One main reason for the segmentation in the literature is type of data that are available. 
For example, if you want to write a paper on venture capital, then you can go to a data vendor that sells venture capital data, but these data will not comprise $100 \%$ of firms that have received venture capital (even if you only focus on recent years) due to the fact that most data vendors obtain such data from voluntary reporting, and others pick up such information where they see it through media and other searches. The venture capital dataset that you obtain will typically only comprise information on venture capital finance, and not have any other information on other forms of finance that the companies in the dataset received, and not have any information on companies that tried to but did not obtain venture capital, and not have any information on companies that did not even seek venture capital. In effect, venture capital studies are isolated by the type of data that are available, and as such, you are typically able to publish venture capital research by only looking at venture capital as the one external source of finance obtained by the companies in the sample, and can do so without analyzing any selection and treatment effects associated with the application for and obtaining of venture capital. Without casting aspersions about the quality of research of others at others, we are guilty of these problems in most, albeit not all, of our studies. One way to get around these data problems is to obtain data from companies themselves, which can be done with surveys, such as that in Cosh et al. (2009) for the U.K. and Robb and Robinson (2014) for the U.S., albeit this approach leads to other problems of representativeness. Another possibility is to try to merge datasets and different sources of information such as that in Cole et al. (2016), but that still leaves unresolved questions that are impossible to resolve with such merging because secondary data in entrepreneurial finance never enables one to know if a firm applied for finance but was subsequently turned down (also a problem with Robb and Robinson, 2014, but not Cosh et al., 2009).

There is a further segmentation of research in entrepreneurial finance other than by type of data: namely, by field of author. Some academics that work on topic are in "finance" (for the purposes herein, we include economics as categorically similar), while others are in “entrepreneurship" (again, for purposes herein, we also include management and strategy as categorically similar). Finance scholars typically do not value publications in entrepreneurship (for an extended explanation why, see Cumming, 2016). The data presented below in section 3 indicate that finance scholars are less inclined to cite papers in entrepreneurship. Consider two more recent examples of papers that were released shortly after writing this paper. We picked these examples because they are extremely recent, and because the topics clearly involve the intersection of papers in finance and entrepreneurship journals. First, in Gompers, Gornall, Kaplan and Strebulaev (2016), the authors deal with the topic "How do Venture Capitalists Make Decisions?” with referencing only one paper from a management or entrepreneurship journal, and that paper is at best tangential to the topic that they study. On Google Scholar in September 2016, we typed (with quotes for a more restrictive search) "Venture Capital Decision" and up came over 1000 papers, virtually all of which are published in management and entrepreneurship journals, and some of these papers have over 1000 citations on Google Scholar, and many have titles that are extremely similar to the Gompers et al. study with the words "venture capital” and 
“decision” in the title (e.g., Gerasymenko, De Clercq and Sapienza, 2015; Iriyama, Li, and Madhaven, 2010; Dushnitsky and Lavie, 2010; Hill, Maula, Birkinshaw, and Murray, 2009; Wuebker, Hampl and Wüstenhagen, 2015; see also Manigart et al., 2002; Sapienza et al., 1996; Wright et al., 2004, 2005). Also, work on venture capital and private equity performance tends to be segmented by the use of particular data, with datasets such as those from Thompson being publishable and acknowledged in finance work (Harris et al., 2014), but data from CEPRES (Cumming and Walz, 2010), CMBOR, Pitchbook (Johan and Zhang, 2014), and VICO (Bertoni et al., 2011) being less often recognized in finance journals (although there are some exceptions, such as Franzoni et al., 2012 with CEPRES data, Johan and Zhang, 2016 with Pitchbook data, and Nikoskelainen and Wright, 2007 with CMBOR data). ${ }^{2}$

Finally, it is noteworthy that there is not merely segmentation in entrepreneurial finance across journals in finance versus entrepreneurship, but also within journal fields. Specifically, entrepreneurial finance papers in the three leading finance journals - the Journal of Finance, Journal of Financial Economics, and Review of Financial Studies - often do not reference papers on the exact same topic in the second tier finance journals. As one example that is very familiar to us, compare Cumming, Fleming and Schwienbacher (2005, first distributed as a working paper in 2001) to Gompers, Kovner, Lerner, and Scharfstein (2008, first distributed as a working paper in 2005). We understand that the reason for this typical exclusion is that the papers in the top three finance journals are typically only obliged to reference other papers published in finance journals at the same level. In short, entrepreneurship scholars should not feel completely isolated from being referenced in finance research, as the level of segmentation in entrepreneurial finance in many cases is within the top three finance journals.

In other academic fields outside entrepreneurial finance, academics have shown collective concern when prior research is not properly cited; for example, see the work linking economics and medicine which has been featured prominently on Retraction Watch, ${ }^{3}$ Economic Job Market Rumors, ${ }^{4}$ and numerous blogs. ${ }^{5}$ But in entrepreneurial finance, when there is not proper reference to prior work, no one appears to speak up.

Segmentation in entrepreneurial finance work can have negative consequences. Briefly, these consequences can be summarized as follows. First, it encourages some authors to submit the exact same paper at the exact same time to a finance journal and an entrepreneurship journal,

\footnotetext{
${ }^{2}$ Other excellent research based on new datasets and topics includes but is not limited to Bertoni and Groh (2014), Butticè et al. (2017), Colombo et al. (2015), Croce and Marti (2016), Meuleman et al. (2014), Tykvova (2016 ), Wright et al. (2016). ${ }^{3}$ http://retractionwatch.com/2016/05/26/economists-go-wild-over-overlooked-citations-inpreprint-on-prenatal-stress/

3 http://retractionwatch.com/2016/05/26/economists-go-wild-over-overlooked-citations-in-preprint-on-prenatal$\underline{\text { stress/ }}$

${ }^{4}$ https://www.econjobrumors.com/topic/new-family-ruptures-aer-nber-is-rip-off-of-obscure-paper

${ }^{5}$ The most referenced blog on point appears to be here https://gborjas.org/2016/06/30/a-rant-on-peer-review/
} 
in the expectation that they will not be caught because the editors and referees are typically quite distinct. See Cumming (2016) for further discussion. Second, the lack of communication across fields can lead to serious mistakes which in turn lead to incorrect public policy decisions, for example in relation to research on the impact of public policy toward venture capital in which there widely cited work based on rankings of the UK venture capital market as the worst in the world, and countries like Austria, Hungary and Iceland as the best venture capital markets in the world (for a detailed explanation, see Cumming, 2011a,b, 2014, 2016). Some of these problems could have been avoided with a more careful review of work published in entrepreneurship journals, and a less blind reliance on finance and economics journals. This example shows that there is a clear harm from networked based reading and citation patterns.. ${ }^{6}$

Romer (2016) and Smolin (2007) discuss problems with the advancement of macroeconomics and physics, respectively. In part, they refer to networked researchers that have characteristics of "tremendous self-confidence", "a sense of identification with the group akin to identification with a religious faith or political platform", and "a disregard for and disinterest in ideas, opinions, and work of experts who are not part of the group". Some of these characteristics seem quite common in the finance arena. Among other things, Cumming (2016) reports that finance professors view work done by non-finance professors extremely negatively, such that the worst finance journal is better than an entrepreneurship or management journal, and scantly ever cite management journals. Likewise, Romer and Smolin highlight "a strong sense of the boundary between the group and other experts", and "a tendency to interpret evidence optimistically, to believe exaggerated or incomplete statements of results, and to disregard the possibility that the theory might be wrong”, among other things. It is well known that finance papers do not have to cite non-finance papers to get published in finance journals. In fact doing so could lead to a lower chance of your paper being accepted by a finance journal. So the sense of boundary is extremely strong. Further, it is widely regarded in the entrepreneurial finance area that if you have a result that some gatekeepers do not like, or competes with other finance authors with differential access to finance journals, then you are best to go to entrepreneurship or management to try to publish such results. In short, there is the impression at least among some in venture capital and private equity that these characteristics are not only common among those in macroeconomics and physics but also among some of those that are gatekeepers in entrepreneurial finance.

In the next section, we conduct an empirical analysis of citation patterns that are at a general level considering the high degree of segmentation in the field.

\footnotetext{
${ }^{6}$ Oddly enough, other work in venture capital shows that venture capitalists that rely on the friends for deal flow similarly end up with worse results. See Gompers at al. (2016b). Of course, we don't want to fall into a trap of missing citations, as this is not a full review of all papers in the area. We acknowledge there are other authors that are active as well in the finance area in entrepreneurial finance, including, e.g., Chemmanur et al. (2014) and Puri and Zarutskie (2012).
} 


\section{Trends in Google Scholar Data}

In this section, we take a stab at integrating an analysis of entrepreneurial finance in entrepreneurship and finance journals. To some degree, we hope our first look helps reflect on where the "action is" in the segmented field, and how developments over the past decade have helped shaped this landscape, and where there are opportunities to break down pigeon holes or silos in future years to come.

We make use of Google Scholar citation data by year to the topics Entrepreneurial Finance, Venture Capital, Private Equity, Private Debt, Trade Credit, Crowdfunding, and IPOs (hereafter the "entrepreneurial finance topics") for the following sixteen journals (alphabetically): Academy of Management Journal (AMJ), Administrative Science Quarterly (ASQ), Entrepreneurship Theory and Practice (ETP), Journal of Banking and Finance (JBF), Journal of Business Venturing (JBV), Journal of Corporate Finance (JCF), Journal of Finance (JF), Journal of Financial and Quantitative Analysis (JFQA), Journal of Financial Economics (JFE), Journal of International Business Studies (JIBS), Journal of Management Studies (JMS), Management Science (MS), Research Policy (RP), Review of Financial Studies (RFS), Strategic Entrepreneurship Journal (SEJ), and Strategic Management Journal (SMJ). ${ }^{7}$

Figure 1 shows the total number of journal hits to these different journals for all of the entrepreneurial finance topics from 2000-2016. The citation patterns pick up by year each journal that was mentioned in a paper that was pertinent to one of these entrepreneurial finance topics, and/or published a paper on one of these entrepreneurial finance topics. The greatest share of activity comes from JF, followed by JFE, MS RFS, JBV, ResPol, SMJ, AMJ, ASQ, JBF, JFQA, ETP, JMS, JCF, JIBS, and SEJ. Note that the citation statistics do not mean, for example, that a paper on venture capital was cited from the Journal of Finance; instead, it means that a paper that referred to "venture capital" also referred to a paper in the Journal of Finance that may or may not have been on the topic of venture capital. Hence, the citation counts track the influence of different journals on topic areas.

\section{[Figures 1 About Here]}

Figure 2 shows the trends in citation patterns to different areas in entrepreneurial finance. All topics are trending upwards. But perhaps most notable, since 2007, crowdfunding research has gained significantly in popularity, partly spurred on by early theoretical and empirical work published on donations and rewards based crowdfunding (Belleflamme, Lambert, and Schwienbacher, 2014; Mollick, 2014), and equity crowdfunding (Ahlers et al., 2015).

\footnotetext{
${ }^{7}$ We thank the reviewers for suggesting many of these journals. There are many other excellent journals that publish on topic. Our analysis is not meant to be exhaustive here. Future research could explore other important journals.
} 
[Figure 2 About Here]

Table 1 presents a panel regression analysis of the data presented in Figures 1 and 2. The sample is a panel of the sixteen journals excluding SEJ. The regressions are an extremely simple setup: the left-hand-side variable is the number of citations per year per journal for the different topic areas in entrepreneurial finance as indicated in each column. The right-hand-side variables include journal fixed effects, along with variables for a time trend (to account for a cumulative increase in citations over time and growing interest in the topic area and greater availability of data over time; somewhat consistent with the general linear patterns that appear in Figure 2), a lag of the number of Google Scholar hits for the topics pertaining to each area of entrepreneurial finance (past papers inspire future papers), and a dummy variable equal to 1 for the years 20072016. The post 2006 variable captures a host of issues such as rise in entrepreneurial activities, gig economy, and new forms entrepreneurial finance such as crowdfunding. The variable is particularly important as it captures the effect that goes beyond the other two control variables: the time trend each year, and the prior number of entrepreneurial finance citations.

Note that because different journals in finance and entrepreneurship, and certain authors in particular, simply do not cite one another, as discussed in the prior section, in the specifications we examine overall citations levels as a measure of the flow of ideas and interest in ideas overall.

The data in column 1 in Table 1 are consistent with the view that there was a positive and significant (at the 5\% level) effect of the post-2006 variable on VC citations per year. The economic significance is such that citations to VC increased by $12.4 \%$ relative to the average level of citation activity per year across the journals in the sample, rather than being attributable to any particular journal.

[Table 1 About Here]

Similarly, the data in column 3 similarly indicate that post 2006 there was a positive and significant effect (at the 1\% level) on PE citations per year. The economic significance is such that citations to PE increased by $26.2 \%$ relative to the average level of citation activity per year across the journals in the sample. ${ }^{8}$ And in column 7, post 2006 there was a positive and significant effect (at the 5\% level) on IPO citations per year, with the economic significance at $17.1 \%$.

To further consider the robustness of the post 2006 effect, we tried different variables related to the post 2006 variable with a lagged variable for a dummy=1 for years 2006 and

\footnotetext{
${ }^{8}$ Note that in an earlier version of this paper, we reported the analysis in Table 1 with a subset of 2 finance journals and 4 management journals, and the findings were extremely similar, with the exception that the economic significance of the post 2006 variable was greater for venture capital and private equity.
} 
onwards, 2005 and onwards, etc., and lead variables for 2008 and onwards, and 2009 and onwards, etc. Those variables cannot be included simultaneously with the 2007 and onwards variable since they are highly correlated (>0.8) with the 2007 and onwards variable, so we used them in separate regressions. We do not report those regressions here for reasons of conciseness, and instead briefly explain the results. First, for venture capital, private equity, and IPOs, the post 2006 variable at plus 1, plus 2, minus 1, and minus 2 remained significant, but the economic and statistical significance was lower for plus 2 and minus 2 for all three dependent variables. For private equity, the economic and statistical significance was marginally higher for plus 1 and marginally lower for minus 1, relative to the 2007 post 2006 variable reported in Table 1. For IPOs, the economic and statistical significance was marginally higher for minus 1 and marginally lower for plus 1, relative to the post 2006 variable reported in Table 1. At plus 3 and minus 3, the modified variable is statistically insignificant for venture capital, private equity, and IPOs. Likewise, for the trade credit, debt, and angel variables, all of the modified variables for minus 1 , 2, and 3 , and plus 1,2 , and 3 are statistically insignificant.

Some further evidence consistent with a structural shift since 2007 is presented in Table 2 for cross-citation patterns. As we have explained above, first, entrepreneurship journals are, by design, interdisciplinary. Second, finance journals are, by design, disciplinary focused, Therefore, it follows that there would be more citations from entrepreneurship to finance than from finance to entrepreneurship. A null hypothesis is that the citation patterns have to do with the ex-ante focus of the journals, rather than the ex-post choices of specific authors. In fact, it lends itself to empirical investigation.

Table 2 shows that from 2000 to 2006, 53.67\% of venture capital papers that cited a finance journal also cited at least one other finance journal, while only $21.29 \%$ also cited an entrepreneurship journal and $32.80 \%$ also cited a management journal; these statistics of segmentation in venture capital with finance declined to $45.90 \%$ over 2007-2016, and improved with cross-references to entrepreneurship to $21.29 \%$ and management to $32.80 \%$. Table 2 further shows that from 2000 to 2006, 58.07\% of private equity papers that cited a finance journal did also cited a different finance journal in 2000-2006, and only $18.25 \%$ cited an entrepreneurship journal and $23.68 \%$ also cited a management journal; these statistics of segmentation diminished in finance to $53.50 \%$ for finance cross-references, over 2007-2016, and improved for entrepreneurship only to $18.30 \%$ and management to $28.21 \%$. So, while these percentages extremely high and show a massive amount of segmentation in the literature, despite the fact that venture capital and private equity papers appeared in entrepreneurship and management journals long before these topics were ever mentioned in finance journals, these statistics on segmentation in finance journals are going down over time.

Note that Table 2 also shows segmentation in entrepreneurship journals and management journals for venture capital and private equity papers. For example, venture capital papers with a reference to an entrepreneurship journal are more likely to also reference management journals than other entrepreneurship journals or finance journals in both periods 2000-2006 and 2007- 
2016. Papers in venture capital with reference to management journals are more likely to reference other management journals than other entrepreneurship or finance journals in 20002006 and 2007-2016. Nevertheless, relative to venture capital papers, private equity papers that reference entrepreneurship or management journals are more likely to also have reference to finance journals, and to that extent private equity appears less segmented from entrepreneurship and management references accommodating finance references despite the fact that private equity finance references are less accommodating of entrepreneurship and management references. We leave the analysis of these citation patterns and that for other related topics for future scholars. See also the discussion in the next section immediately below.

[Table 2 About Here]

Note that in Table 1 we do not have a regression for one of the topics referred to in this paper: crowdfunding. There was scant reference to crowdfunding prior to 2007 (some years 1 or 2 references, and some years nothing at all). Hence, the regression cannot include a test of the 2007 effect as we would have to start the sample in 2007. Perhaps one thing to note is that crowdfunding research started later than it perhaps should have, while currently crowdfunding is one of the most active and fastest growing research areas in entrepreneurial finance. Anecdotally, we are aware of silos growing among certain pockets of researchers similar to venture capital research in the 1990s, but remain hopefully that the field will grow more along the open lines of work on IPOs. Likewise, we do not report a regression in Table 1 for the search term in Google Scholar for "entrepreneurial finance" as the results were insignificant, and because papers are often on the topic of entrepreneurial finance without containing the words entrepreneurial finance (for example, many venture capital, private equity, and IPO papers fit into this category).

In light of the analysis in this section, in the next section below, we discuss some specific topics that we believe will become important or should be important in our view in future years.

\section{The Future of Entrepreneurial Finance and Some Unanswered Research Questions}

As we highlighted in the introduction, entrepreneurial finance offers fantastic opportunities for a lifetime of research topics. The main theme is that for private entrepreneurial investments, finance is not merely about providing the capital, but also providing the advice, networks, monitoring, and governance, and mitigating information asymmetries and agency

costs between different parties. Increasingly, academics are developing better datasets and measures to quantify these information, advice, and monitoring variables in different contexts.

Post 2006 there has been a marked surge in research on entrepreneurial finance, perhaps associated with the rise in entrepreneurial activities, gig economy, and new forms entrepreneurial finance such as crowdfunding. This period also coincided with the launch of the Strategic 
Entrepreneurship Journal. But there is still a long way to go and ample scope for future research papers. Some questions that could be raised in future research include the following. First, why do venture capital and private equity contracts differ so drastically in different countries? Explanations offered include tax (Gilson and Schizer, 2003), sophistication and experience, legal rules, legal enforcement and culture (Cumming and Johan, 2013). But there is little consensus amongst findings across different papers and different authors, and different hand collected datasets yield vastly different results. Further, there could be more work on the relation between legal and cultural settings in investment outcomes (see also Nahata et al., 2013; Zahra, 2014)

Second, for non-venture capital and private equity investments, what are the investment terms, how do they vary across regions and countries, the characteristics of investing parties, and over different time periods? There is scant research on contractual terms for angel investments, and private debt investments, and particularly in different countries and institutional settings.

Third, under what contexts do different types or sources of entrepreneurial finance complement one another to enable superior entrepreneurial outcomes? For example, are bank debt, VC, trade credit, angel investment, and crowdfunding complements or substitutes? Most entrepreneurial finance papers make use of one source of capital only, due to the segmented nature of the data. And relatedly, are financing terms (cash flow rights, control rights, valuation) in entrepreneurial finance different depending on the presence of different sources of capital financing the firm at different points of time? Which forms of entrepreneurial finance enable the best outcomes for entrepreneurial firms, and under which contexts (by industry, stage of development, team size, region, country, gender, etc.) Some innovative work along these lines and a further discussion is found in McCahery and Vermeulen (2016).

Fourth, given the newness of the fields, there are a number of research questions on crowdfunding and angel investment. For example, what are the most effective sets of rules for equity crowdfunding? How distinct are different crowdfunding platforms and do they make a difference in respect of financing outcomes for entrepreneurial firms? In respect of angel investment, the data to date are so scant that it is hard to even quantify the overall investment levels in different countries, and even within the US. A substantial amount of work could be done improving the quality of data across countries.

Finally, there could be substantially more studies on the extent to which there gender and racial biases in different sources of entrepreneurial finance. Venture capital is notorious for apparently being gender biased, at least in the media with famous lawsuits such as one involving Kleiner Perkins. To what degree is gender bias reduced in crowdfunding, and does the interplay between crowdfunding and venture capital reduce gender bias? And how do these biases vary across countries and regions?

The segmented field of entrepreneurial finance gives rise to a separate stream of research questions about the development of the field in the spirit of the empirical analysis in the prior 
section. First, it would be useful to document cross-citations across the journals. How many entrepreneurial finance papers publish in economics/finance journals cite entrepreneurship/management studies? How many entrepreneurial finance papers in entrepreneurship/management journals cite finance journals?

Second, it would be useful to track networks of authors within the different fields. How often do 'outsiders' in entrepreneurial finance (i.e., non-colleagues and non-PhD students of folks that worked on topic with A-tier publications) break in to the top 3 finance journals?

Third, it would be useful to document the effects of networks and absence of crossreferencing. What is the incidence of false or non-reliable or non-replicable papers in entrepreneurial finance, and are such papers more or less often authored by those that are 'networked' in finance or entrepreneurship journals? To what extent do policymakers and practitioners reference entrepreneurial finance studies published in management versus finance journals, and which is associated with greater success or failure? How many practitioners and policymakers have relied on research, such as work on public policy towards entrepreneurial finance, and what is the dollar benefit or harm from such a reliance?

Fourth, it would be useful to benchmark whether or not researchers "study the right thing” so to speak. That is, does the frequency of papers in different topics in entrepreneurial finance reflect the frequency of usage of different forms of entrepreneurial finance in practice? And which journals get the balance right? Does the study of new modes of entrepreneurial finance (e.g., venture capital in the 1970s and 1980s, and crowdfunding since 2010) more often appear first in finance or management journals?

Finally, how do scholars reconcile what differences in what are considered to be valid datasets in entrepreneurial finance, apart from not citing one another when results from such data are different? What are the research consequences of groups that control access to datasets in entrepreneurial finance and reveal research topics of interest to obtain such data that are deemed to be the appropriate for publication in certain journals? That is, do such data centers encourage or stifle research in entrepreneurial finance? Or does it shift the focus of research to different types of people, and reinforce networks of researchers in entrepreneurial finance and accompanying citation patterns? (Cumming, 2016, provides some disturbing anecdotes).

These are merely a sampling of topics that could be the focus of future study, both of entrepreneurial finance, and of those that have done work on entrepreneurial finance. Just as the topics in entrepreneurial finance are fascinating, so too are the personalities and dynamics of the folks that engage in the study of these topics. 


\section{Concluding Remarks and Hopes for the Future}

At the risk of overgeneralizing, in this paper we have characterized the same field of entrepreneurial finance across segmented finance and entrepreneurship journals as sharing an unequal relationship in which entrepreneurship scholars appear to be more welcoming of research from finance than finance scholars are of research from entrepreneurship. The silos in different journals, among other things, has given rise to issues in the development of entrepreneurial finance that resemble macroeconomics (Romer, 2016) and physics (Smolin, 2007).

Despite finance and entrepreneurship colleagues working in the same business school buildings at different universities around the world, and many on overlapping topic areas, they do not talk to one another and typically do not cite one another. This is unfortunate.

One of the main reasons for the incredible degree of segmentation of research in entrepreneurial finance is the poor quality of data that are available for entrepreneurial finance studies. Unlike publicly traded companies on stock exchanges, in most countries in the world (perhaps with the exception of some Scandinavian countries) there are no mandated reporting requirements and datasets on what it is that privately held firms do, and where they obtain their capital.

The poor quality of data to date enables a massive number of topics that could be explored in future research. It also enables research about the researchers themselves, as discussed herein. We hope to see substantially more work in both directions for many years to come. 


\section{References}

Ahlers, G.K.C., Cumming, D.J., Guenther, C., Schweizer, D. 2015. Signaling in equity crowdfunding, Entrepreneurship Theory and Practice 39: 955-980.

Barry, C., Muscarella, C., Peavy, J. Vetsuypens, M. 1990. The role of venture capital in the creation of public companies: Evidence from the going-public process. Journal of Financial Economics 27: 447-476.

Belleflamme, P., Lambert, T., \& Schwienbacher, A. 2014. Crowdfunding: Tapping the right crowd, Journal of Business Venturing 29: 585-609.

Bertoni, F. Colombo, M.G., Grilli, L. 2011. Venture capital financing and the growth of high-tech startups: Disentangling treatment from selection effects, Research Policy 40(7): 1028-1043

Bertoni, F., Groh, A.P., 2014. Cross-Border Investments and Venture Capital Exits in Europe. Corporate Governance: An International Review 22: 84-99.

Butticè, V., Colombo, M.G., Wright, M. 2017. Serial Crowdfunding, Social Capital, and Project Success, Entrepreneurship Theory and Practice 41: 183-207.

Chemmanur, T.J., Loutskina, E., Tian, X. (2014). Corporate venture capital, value creation, and innovation, Review of Financial Studies 27: 2434-2473

Cole, R., Cumming, D.J., Li, D. 2016. Do banks or VCs spur small firm growth? Journal of International Financial Markets, Institutions and Money 41: 60-72.

Coombs, J.E., Deeds, D.L., Ireland, R.D. 2009. Placing the choice between exploration and exploitation in context: a study of geography and new product development, Strategic Entrepreneurship Journal 3: 261-279.

Colombo, M.G., Franzoni, C., Rossi-Lamastra, C. 2015. Internal Social Capital and the Attraction of Early Contributions in Crowdfunding Projects, Entrepreneurship Theory and Practice 39: 75-100.

Cosh, A., Cumming, D.J., Hughes, A. 2009. Outside Entrepreneurial Capital. Economic Journal 119: 1494-1533.

Croce, A., Marti, J. 2016. Productivity growth in private equity-backed family firms, Entrepreneurship Theory and Practice 40: 657-683.

Cumming, D.J., 2011a. "Misinforming the Public about Public Policy towards Venture Capital” Venture Capital: An International Journal of Entrepreneurial Finance 13(1): 99-102.

Cumming, D.J., 2011b. "Review Essay: Public Policy and the Creation of Active Venture Capital Markets” Venture Capital: An International Journal of Entrepreneurial Finance 13(1): 75-94.

Cumming, D.J. 2014. Public economics gone wild: Lessons from venture capital, International Review of Financial Analysis 36: 251-260. 
Cumming, D.J., 2016. “Publishing in Finance versus Entrepreneurship/Management Journals” in T. Clark, M. Wright, and D. Ketchen, eds., How to Get Published in Top Management Journals, Wiley, forthcoming

Cumming, D.J., Fleming, G., Schwienbacher, A. 2005. Liquidity risk and venture capital finance, Financial Management 34(4): 77-105.

Cumming, D.J., Johan, S.A. 2013. Venture Capital and Private Equity Contracting: An International Perspective, 2nd Edition, Elsevier Science Academic Press.

Cumming, D.J., Sapienza, H.J., Siegel, D., Wright, M. 2009. International entrepreneurship: managerial and policy implications, Strategic Entrepreneurship Journal 3: 283-296.

Cumming, D.J., Schmidt, D., Walz, W. 2010. Legality and venture capital governance around the world, Journal of Business Venturing 25: 54-72.

Cumming, D.J., Vismara, S. 2016a. "De-segmenting Research in Entrepreneurial Finance" Venture Capital: An International Journal of Entrepreneurial Finance, forthcoming

Cumming, D., Vismara, S. 2016b. “A Research Journey into Entrepreneurial Finance,” David B. Audretsch \& Erik E. Lehmann, eds., Companion to Makers of Modern Entrepreneurship. Routledge, Chapter 7.

Cumming, D.J., Walz, U. 2010. Private equity returns and disclosure around the world, Journal of International Business Studies 41: 727-754.

Dushnitsky, G., Lavie, D. 2010. How alliance formation shapes corporate venture capital investment in the software industry: a resource-based perspective, Strategic Entrepreneurship Journal 4: 22-48.

Felin, T., Zenger, T.R. 2009. Entrepreneurs as theorists: on the origins of collective beliefs and novel strategies, Strategic Entrepreneurship Journal 3: 127-146.

Franzoni, F., Nowak, E., Phalippou, L. 2012. Private equity performance and liquidity risk, Journal of Finance 67(6): 2341-2373.

Gerasymenko, V., De Clercq, D., Sapienza, H.J. 2015. Changing the Business Model: Effects of Venture Capital Firms and Outside CEOs on Portfolio Company Performance, Strategic Entrepreneurship Journal 9: 79-98.

Gilson, R., Schizer, D., 2003. Venture capital structure: a tax explanation for convertible preferred stock. Harvard Law Review 116: 875- 916.

Gompers, P., Kovner, A., Lerner, J., Scharfstein, D. 2008. Venture capital investment cycles: The impact of public markets. Journal of Financial Economics 87(1): 1-23.

Gompers, P.A., Gornall, W., Kaplan, S., Strebulaev, I.A. 2016a. How Do Venture Capitalists Make Decisions? NBER Working Paper No. 22587

Gompers, P.A., V. Mukharlyamov, Y. Xuan, 2016b. The cost of friendship. Journal of Financial Economics, forthcoming. 
Kaplan, S., Lerner, J. 2016. Venture capital data: opportunities and challenges,

Hill, S.A., Maula, M.V.J., Birkinshaw, J.M., Murray, G.C. 2009. Transferability of the venture capital model to the corporate context: Implications for the performance of corporate venture units, Strategic Entrepreneurship Journal 3: 3-27.

Iriyama, I., Li, Y., Madhavan, R., 2010. Spiky globalization of venture capital investments: The influence of prior human networks, Strategic Entrepreneurship Journal 4: 128-145.

Klein, P.G., Mahoney, J.T., McGahan, A.M., Pitelis, C.N. 2013. Capabilities and strategic entrepreneurship in public organizations, Strategic Entrepreneurship Journal 7, 70-91.

Lerner, J., 2009. Boulevard of Broken Dreams: Why Public Efforts to Boost Entrepreneurship and Venture Capital Have Failed - and What to Do about It, Princeton University Press 229pp.

Manigart S, De Waele K, Wright M, Robbie K, Desbrieres P, Sapienza HJ, Beekman A. 2002. Determinants of required return in venture capital investments: a five-country study, Journal of Business Venturing 17(4): 291-312.

Meuleman M. Vanacker T. Manigart S. 2014. Path-dependent evolution versus intentional management of investment ties in science-based entrepreneurial firms. Entrepreneurship Theory and Practice 38(3): 671-690.

McCahery, J.A., Vermeulen, E.P.M. 2016. Venture Capital 2.0: From Venturing to Partnering, Annals of Corporate Governance 1(2), 95-173. http://dx.doi.org/10.1561/109.00000007

Megginson, W., Weiss, K. 1991. Venture capital certification in initial public offerings. Journal of Finance 46 :, 879-903.

Mollick, E.R., 2014. The Dynamics of Crowdfunding: Determinants of Success and Failure, Journal of Business Venturing 29: 1-16.

Nahata, R., Hazaruka, S., Tandon, K. 2014, Success in global venture capital investing: Do institutional and cultural differences matter? Journal of Financial and Quantitative Analysis 49: 1039-1070.

Puri, M., Zarutskie, E. (2012). On the life cycle dynamics of venture-capital-and non-venture-capitalfinanced firms. Journal of Finance 67: 2247-2293.

Robb, A. M., Robinson, D. T. (2014). The Capital Structure Decisions of New Firms. Review of Financial Studies 27: 153-179

Romer, P. (2016) The Trouble with Macroeconomics, The American Economist, forthcoming.

Sapienza, H.J., Manigart, S. Vermeir, W. 1996. Venture capitalist governance and value added in four countries, Journal of Business Venturing 11: 439-469

Sirén, C.A., Kohtamäki, M., Kuckertz, A. 2012. Exploration and exploitation strategies, profit performance, and the mediating role of strategic learning: Escaping the exploitation trap, Strategic Entrepreneurship Journal 6: 18-41. 
Smolin, L. 2007. The Trouble With Physics: The Rise of String Theory, The Fall of a Science, and What Comes Next, Houghton Mifflin Harcourt.

Stuart, T.E., Sorenson, O. 2007. Strategic networks and entrepreneurial ventures, Strategic Entrepreneurship Journal 1, 211-227.

Tykvova, T. 2016 When and Why Do Venture Capital-Backed Companies Obtain Venture Lending? Journal of Financial and Quantitative Analysis, forthcoming.

Wuebker, R., Hampl, N., Wüstenhagen, R. 2015. The Strength of Strong Ties in an Emerging Industry: Experimental Evidence of the Effects of Status Hierarchies and Personal Ties in Venture Capitalist Decision Making, Strategic Entrepreneurship Journal 9: 167-187.

Wright, M., Lockett A., Pruthi, S., Manigart, M., Sapienza, H., Debrieres, P., Hommel, U., 2004. Venture capital investors, capital markets, valuation and information: US, Europe and Asia, Journal of International Entrepreneurship 2: 305-326.

Wright M., Pruthi S., Lockett A. 2005. International venture capital research: From cross-country comparisons to crossing borders, International Journal of Management Reviews 7: 135-165.

Wright, M., Wilson, N., Gilligan, J., Bacon, N., Amess, K. 2016. Brexit, private equity and management British Journal of Management 27(4): 682-686.

Zahra, S.A. 2014. Public and corporate governance and young global entrepreneurial firms, Corporate Governance: An International Review 22(2): 77-83. 
Figure 1. Google Scholar Hits by Topic and Journal

This figure presents the number of Google Scholar hits for the years 2000-2016 for “Entrepreneurial Finance”, “Venture Capital”, “Private Equity”, Entrepreneur Debt (not in quotes to capture papers about entrepreneurs and debt), "Trade Credit", Angel Investor (not in quotes to capture papers about angel investors), Crowdfunding, and IPOs. JF=Journal of Finance; JFE=Journal of Financial Economics; MS= Management Science; RFS=Review of Financial Studies; JBV=Journal of Business Venturing; ResPol=Research Policy; SMJ=Strategic Management Journal; AMJ=Academy of Management Journal; ASQ=Administrative Science Quarterly; JBF=Journal of Banking and Finance; JFQA=Journal of Financial and Quantitative Analysis; ETP= Entrepreneurship Theory and Practice; JMS=Journal of Management Studies; JCF=Journal of Corporate Finance; JIBS=Journal of International Business Studies; SEJ=Strategic Entrepreneurship Journal (started in 2007). A paper in the data appears more than once for each journal that referenced the paper.

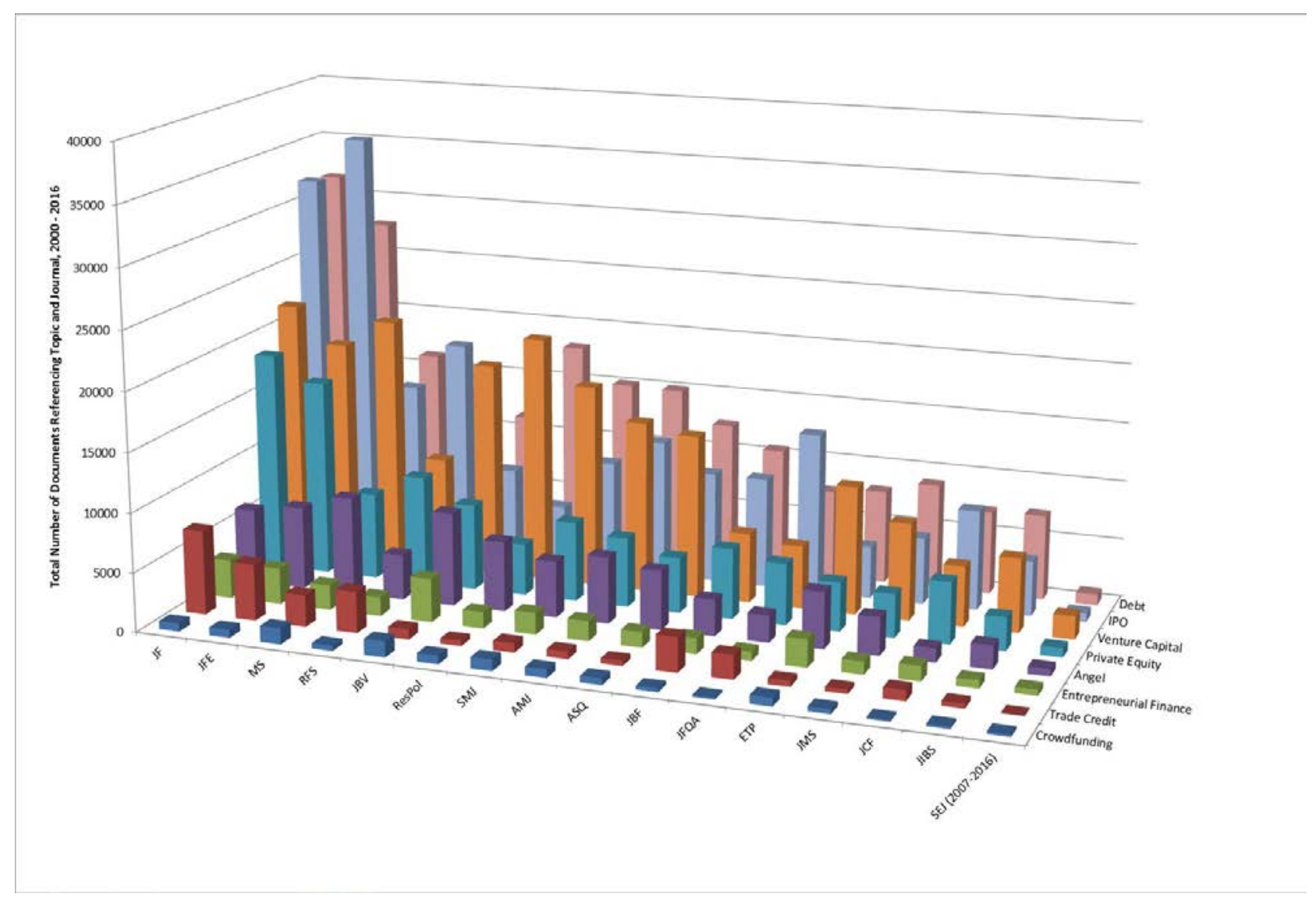




\section{Figure 2. Google Scholar Hits by Topic and Year}

This figure presents the number of Google Scholar hits for the years 2000-2016 for “Entrepreneurial Finance”, “Venture Capital”, “Private Equity”, Entrepreneur Debt (not in quotes to capture papers about entrepreneurs and debt), “Trade Credit”, Angel Investor (not in quotes to capture papers about angel investors), Crowdfunding, and IPOs.

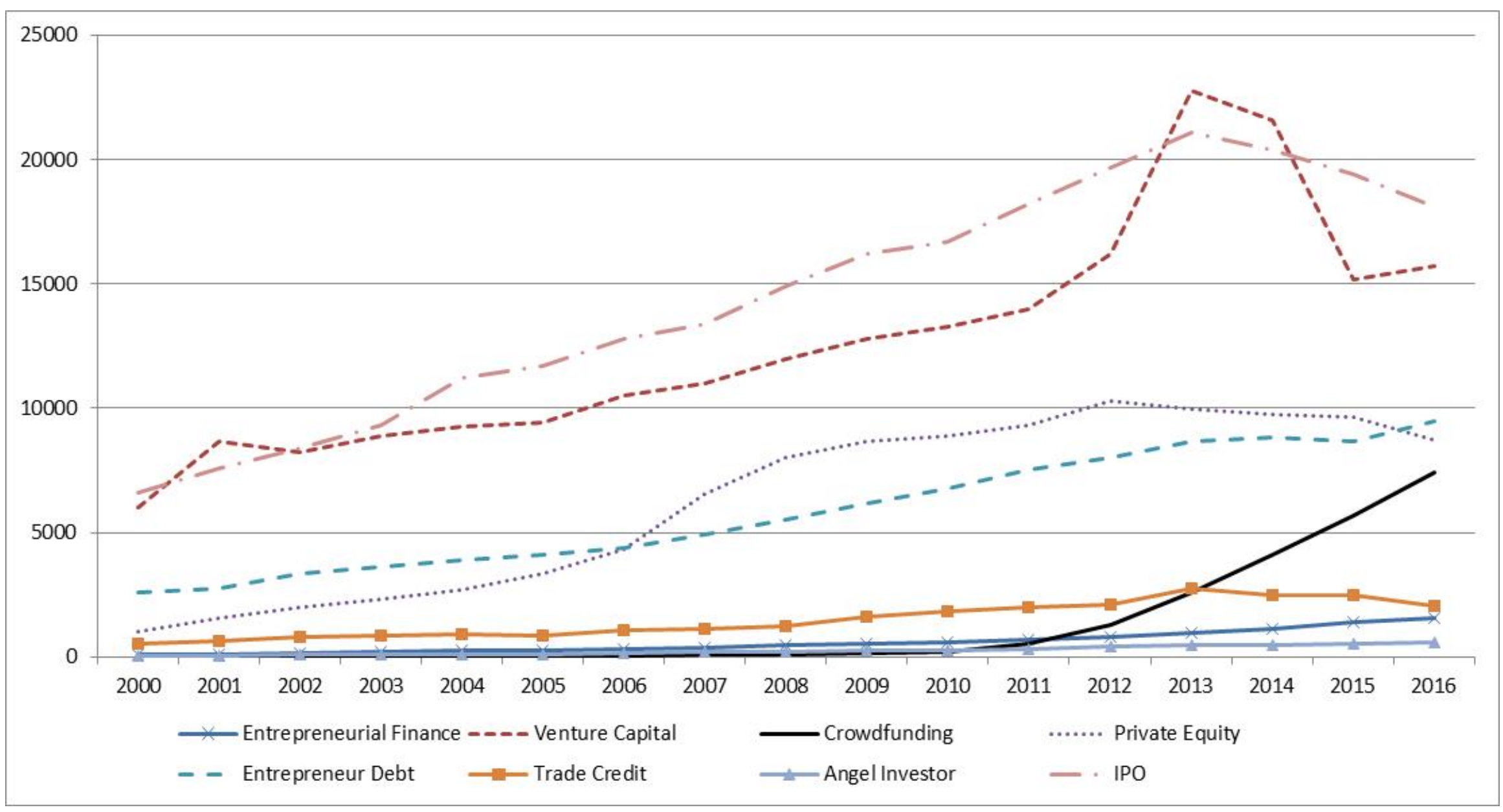




\section{Table 1. Regression Evidence of Citation Counts}

This table presents panel regressions of the determinants of citation counts per year with the journal name and the topic area, for each of the topics Venture Capital, Private Equity, Debt, Trade Credit, Angel, and IPOs. Data are from Google Scholar for the years January 2000 -December 2016. The variable Post 2006 is a dummy variable equal to one for the years 2007-2016, and zero for the other years. The regressions also include a 1-year lag of the prior counts for all areas in entrepreneurial finance to account for prior research spurring future research, and a year variable as a time trend to account for increasing citation patterns over time. Journal fixed effects are used in all of the regressions. *, **, *** Significant at the $10 \%, 5 \%$, and $1 \%$ levels, respectively.

Venture Capital

Private Equity

Debt

Trade Credit

Angel

IPOs

Coefficient

t-statistic

Coefficient

t-statistic

Post 2006 Variable

Lag Prior Counts All Entrepreneurial Finance Fields

Year Trend

\section{Constant}

Number of Observations

Number of Groups

R2 within

R2 overall

$13.11^{* * *}$

0.96

$-0.50$

40

0.76
Coefficient

5.78

$96.372 .50^{* *}$

111.02

$3.62 * * *$

5.78

t-statistic

0.13

Coefficient

$(-19$

0.09

$$
9.59 * * *
$$

34.47

111.38

\subsection{0}

4.64

$-10.18$

\section{$5.70^{* * *}$}

$4.33^{* * *}$

$\begin{array}{cc}0.16 & 14.89 * * * \\ 32.57 & 4.80^{* * *} \\ -0.57 & -0.02\end{array}$

240

15

0.90

0.83

$\begin{array}{ll}-4.19 & -0.27\end{array}$

0.03

0.28

12.38

240

15

0.57

0.46

$7.92^{* * *}$

0.11

$\mathrm{t}-$
statistic

Coefficien

$-0.83$

$-0.83$

0.03

$6.50^{* * *}$

20.81

$7.03^{* * *}$

13.79

1.59

$1.21 \quad-9.19$

$-0.73$

$115.90 \quad 3.15^{* * *}$

15

0.79

0.59 


\section{Table 2. Cross-Citation Patterns in Google Scholar for Venture Capital and Private Equity}

This figure presents the percentage of cross references (only; not journal self-citations) in 2000-2006 and 2007-2016 for papers with "venture capital" and "private equity” for the number of Google Scholar hits for the years 2000-2016 for "Entrepreneurial Finance", "Venture Capital”, "Private Equity”, Entrepreneur Debt (not in quotes to capture papers about entrepreneurs and debt), "Trade Credit", Angel Investor (not in quotes to capture papers about angel investors), Crowdfunding, and IPOs. The figures in bold highlight references that are not cross-references to other types of journals; so, for example, 53.50\% of private equity papers that reference a finance journal in 2007-2016 also reference another finance journal. Finance journals include JBF=Journal of Banking and Finance; JCF=Journal of Corporate Finance; JF=Journal of Finance; JFE=Journal of Financial Economics; JFQA=Journal of Financial and Quantitative Analysis; and RFS=Review of Financial Studies. Entrepreneurship journals include ETP= Entrepreneurship Theory and Practice; JBV=Journal of Business Venturing; ResPol=Research Policy; and SEJ=Strategic Entrepreneurship Journal (started in 2007). Management journals include AMJ=Academy of Management Journal; ASQ=Administrative Science Quarterly; JIBS=Journal of International Business Studies; JMS=Journal of Management Studies; MS= Management Science; and SMJ=Strategic Management Journal; A paper in the data appears more than once for each journal that referenced the paper.

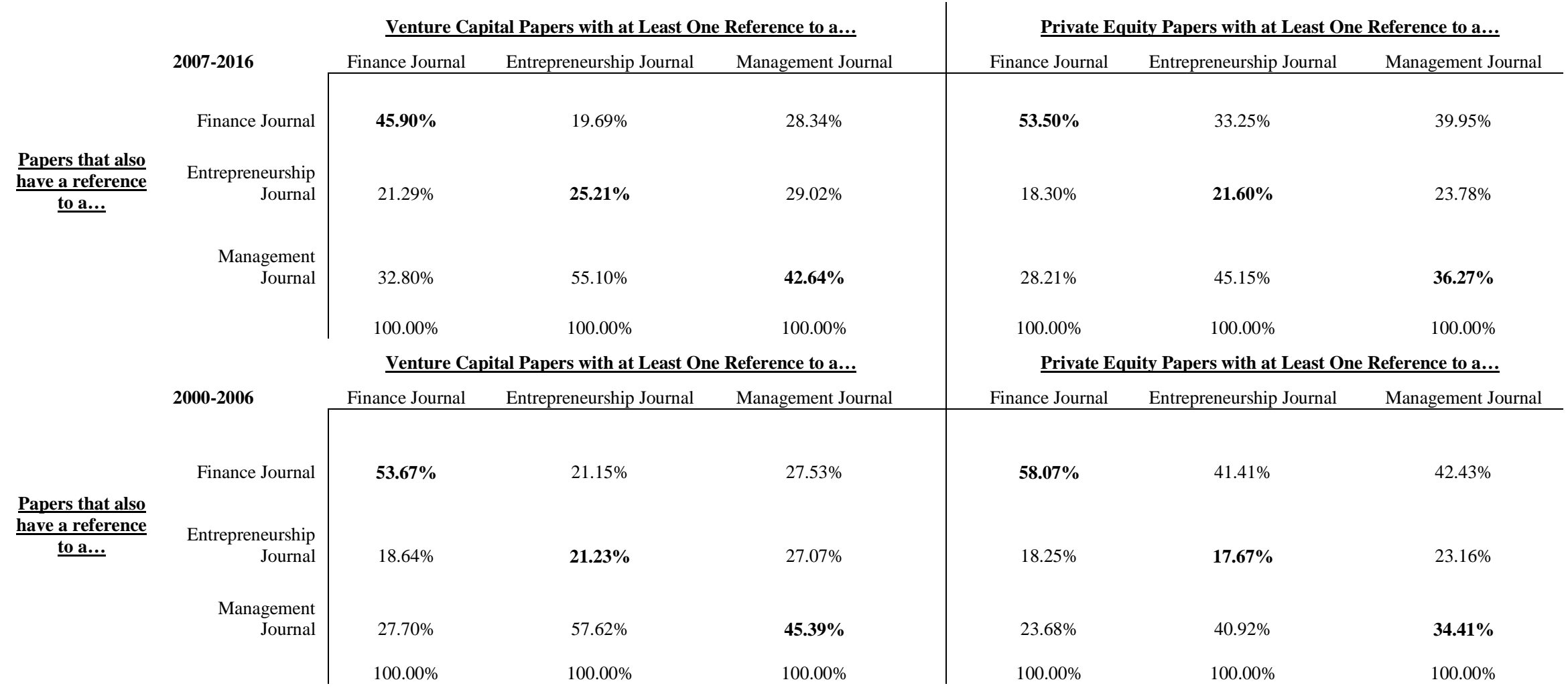


